\title{
Flea (Siphonaptera: Pulicidae) prevalence and first record of Ctenocephalides canis (Curtis, 1826) in domestic dogs in north-central México
}

\begin{abstract}
The objective of the present study was to report the prevalence of fleas and describe for the first time the presence of Ctenocephalides canis (Curtis) in dogs from Gómez Palacio and Lerdo, Durango, México. A total of 217 dogs were inspected, five of them (2.3\%) were parasitized by fleas. The specimens were identified as $C$. canis and $C$. felis fleas. The existence of these ectoparasites in domestic dogs is of public and veterinary concern, due to the putative role of this fleas in the transmission of zoonotic pathogens in the study area.
\end{abstract}

Keywords: fleas, first record, ctenocephalides canis, ctenocephalides felis, domestic dogs, comarca lagunera

\author{
Volume 7 Issue 4 - 2018 \\ Vicente Homero González Álvarez,' Antonio \\ Castillo Martínez, ${ }^{2}$ Adebiyi Abdulhakeem \\ Adeniran, ${ }^{3}$ Mario Alberto Rodríguez Pérez, ${ }^{3}$ \\ Aldo Iván Ortega Morales ${ }^{1,4}$ \\ 'Postgraduate in Sciences in Agricultural Production, \\ Universidad Autónoma Agraria Antonio Narro, Mexico \\ ${ }^{2}$ Postgraduate in Agrarian Sciences, Antonio Narro Agrarian \\ Autonomous University, Mexico \\ ${ }^{3}$ Instituto Politécnico National, Luego Centro de Biotecnología \\ Genómica, Laboratorio de Biomedicina Molecular, Mexico \\ ${ }^{4}$ Department of Parasitology, Universidad Autónoma Agraria \\ Antonio Narro, México
}

Correspondence: Aldo Iván Ortega Morales, Universidad Autónoma Agraria Antonio Narro, Deparment of Parasitology, Peripheral and highway to Santa Fe, Torreón, Coahuila, México, Email agrortega@hotmail.com

Received: April 12, 2018 | Published: July 10, 2018

\section{Introduction}

The domestic dog is parasitized by arthropods like ticks (Acari: Ixodidae), lice (Insecta: Anoplura), and fleas (Insecta: Siphonaptera). Fleas are wingless, with laterally compresed body, obligate ectoparasites, with a very high specialization to live over its host. Commonly, fleas are considered important only as plague of some domestic animals; however, they are important due to their association in the transmission of zoonotic diseases. ${ }^{2}$ Around the world 2574 flea species are known, of which in México there exist eight families, and 172 species corresponding to $7 \%$ of the total fleas of the world, and the two main families are Ceratophillidae with 74 species and Ctenophthalmidae with 45 species. $^{3}$ The domestic dog can be parasitized by two main flea species: Ctenocephalides canis (Curtis) and Ctenocephalides felis (Bouché), and the last being considered the most predominant species worldwide. ${ }^{4}$

Around the world it is known that fleas are vectors of pathogenic agents transmitted to humans and animals with, some of these microorganisms including Bartonella henselae, Rickettsia felis, $R$. typhi, and Yersinia pestis. ${ }^{5,6}$ However, in the last years fleas have been implicated as potential vectors of bacteria belonging to the "Spotted Fever" rickettsia, new genotypes of Bartonella, as well as Coxiella burnetii, Mycoplasma haemominutum, Mycoplasma haemofelis, Anaplasma ovis, A. marginale, A. phagocytophilum, and Ehrlichia canis. ${ }^{7-9}$

In México, reports over the presence of $C$. canis and C. felis parasitizing domestic dogs in the central and south part of the country; ${ }^{10-12}$ nevertheless, in the north-central part there are no reports over the presence of these flea species parasitizing domestic dogs. The objective of the present study was to identify the flea species that parasitize domestic dogs of Gomez Palacio and Lerdo, in Durango state, México.

\section{Material and methods}

Fleas were collected during June to September 2016 in Gómez Palacio $\left(25^{\circ} 32^{\prime}\right.$ and $25^{\circ} 54 \mathrm{~N},-103^{\circ} 19^{\prime}$ and $\left.103^{\circ} 42 \mathrm{O}\right)$ and Lerdo $\left(25^{\circ} 10^{\prime}\right.$ and $25^{\circ} 47^{\prime} \mathrm{N},-103^{\circ} 20^{\prime}$ and $\left.-103^{\circ} 49^{\prime} \mathrm{O}\right)$, both cities in Durango state, located at north-central part of México, at an average altitude of 1,150 and $1,140 \mathrm{msnm}$, respectively. Both cities have a very dry semi-arid climate, with a temperatura ranging from $14-22^{\circ} \mathrm{C}$, summer rains $(100-400 \mathrm{~mm})$, and a scrub and pasture like vegetation (Figure 1). ${ }^{13,14}$

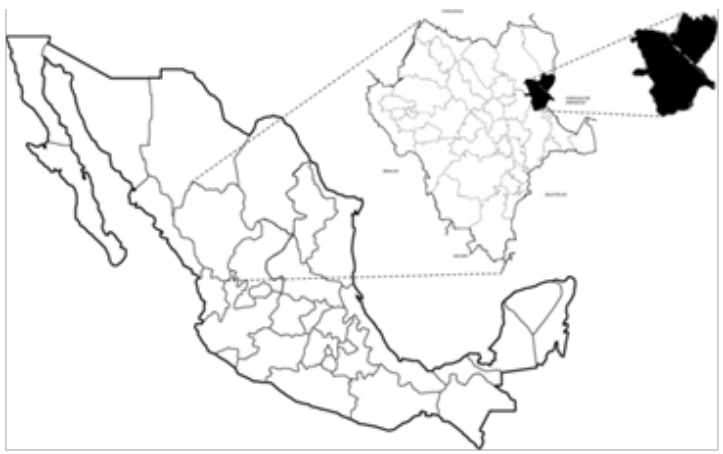

Figure I Location of the study area. 
Each domestic dog in this study was visually inspected, and as described by Rinaldi et al., ${ }^{15}$ with the sites of predilection by fleas were specially inspected. All specimens were collected manually using entomologic forceps, and deposited in $70 \%$ alcohol containing vials, and transferred at the Laboratorio de Biología Molecular, Departamento de Parasitología, Universidad Autónoma Agraria Antonio Narro, Unidad Laguna. The taxonomic identification of the specimens was realized using stereoscopic microscope (Zeiss Discovery V8), according to adecuate taxonomic keys. ${ }^{16}$

\section{Results and discussion}

A total of 217 female and male domestic dogs of different age and breed were inspected to detect the presence of fleas. Only in five dogs, fleas were observed for a total prevalence of $2.3 \%$ (Table 1). For each dog, 30 fleas were collected for a total of 150 specimens, of which, 138 (92\%) were consistent with $C$. felis description, and 12 (8\%) with C. canis description. The identification of the specimens was limited only to genera and species, but not to determine the sex; furthermore, during the study no other flea species were identified.

Table I Site and characteristics of the sampled animals and specimen collected in the study

\begin{tabular}{lllll}
\hline Locality & Sample & Sex & \multicolumn{2}{l}{ Specimen } \\
\hline Gómez Palacio & & & C. canis & C. felis \\
& I & Male & I & 29 \\
& 2 & Female & 5 & 25 \\
& 3 & Female & 2 & 28 \\
Lerdo & & & & \\
& 4 & Female & 2 & 28 \\
& 5 & Female & 2 & 28 \\
Total & & & 12 & 138
\end{tabular}

In Figure 2, differences between the two flea species are shown. It could be noted the presence of the pronatal comb (with six spines for both species), as well as the rounded margin in the case of $C$. canis; however, the head has a longer and more pronunced angle in C. felis. It is notably to highlight that the two species were found as mixed infestation in the studied dogs; however, $C$. felis was the most prevalent flea (Table 1), as stated by Beugnet et al. ${ }^{4}$ In the scientific literature, there are reports of mixed infections by $C$. canis and $C$. felis, ${ }^{11,15,17}$ similar to the observations in our study, were all the positive dogs presented infestation of at least one specimen of both species. It is known that the presence of $C$. canis has more restricted geographic distribution, and that the presence of $C$. felis has increased, even displacing C. canis, from which the reasons are not well. ${ }^{11}$ In the present study, more than $90 \%$ of the specimens were $C$. felis.

Our results are in agreement with the report of Beugnet et al. ${ }^{4}$ who mentioned that in the domestic dog the most prevalent flea species around the world is C. felis. In our study, the prevalence observed for C. felis was of $92 \%$, surpassing the $38 \%$ reported by Hernández-Valdivia et al. ${ }^{11}$ in Aguascalientes, México; as well as the $46.4 \%$ reported by Orozco-Murillo et al. ${ }^{17}$ in Valle de Aburrá, Colombia, and the $16.3 \%$ reportead by Rinaldi et al. ${ }^{15}$ in Campania, Italia. The obtained prevalence in this study $(2.3 \%)$ with respect to $C$. canis, contrasts with the report of Nuchjangreed and Somprasong, ${ }^{18}$ in Pattaya, district of Thailand, where they found this flea species in $11.7 \%$ of the examined dogs; while Jafari-Sohoorijeh et al. ${ }^{19}$ in Shiraz, Iran, reported a prevalence of $13.7 \%$, and Cruz-Vázquez et al. ${ }^{10}$ in Cuernavaca, Morelos a total of $16.8 \%$ of C. canis in infested dogs respectively. However, Bahrami et al. ${ }^{20}$ and Jamshidi et al. ${ }^{21}$ described prevalences as high as $28.8 \%$, in Islam, and $29.4 \%$, in Tehran, Iran; respectively. While Orozco-Murillo et al. ${ }^{17}$ in Valle de Aburrá, Colombia, reported a highest prevalence for C. canis $(53.6 \%)$.

Worldwide, fleas has a special role in the transmission of pathogens. Historically, diseases such as Plague and Murine Tifus are of the most important in terms of infection of humans. Although the dog is less susceptible to $Y$. pestis infection, and its role in the dissemination of the disease is not well established, epidemiological data supports that some patients infected with plague, shared the bed with dogs, suggesting that fleas on these dogs played an important role. ${ }^{22}$ Furthermore, other pathogens like Bartonella henselae, and some Rickettsia spp, can be transmitted to humans during the exposure to contaminated fleas, that ocasionally feed on humans ${ }^{6}$. It is important to control these ectoparasites by using cutaneous or systemic ectoparasiticides, ${ }^{23}$ by means of oral administration of natural products ${ }^{24}$. As well, topical solutions are an excellent option to control fleas, this product could be used to prevent and eradicate infestations. ${ }^{25}$ Furthermore, other products, can help to prevent reinfestations up to five weeks. ${ }^{26}$ Even, recent investigations suggests that the utilization of entomopathogenic fungi can be used in order to reduce the employment of chemical products in order to protect animal, human and environmental health. ${ }^{27}$
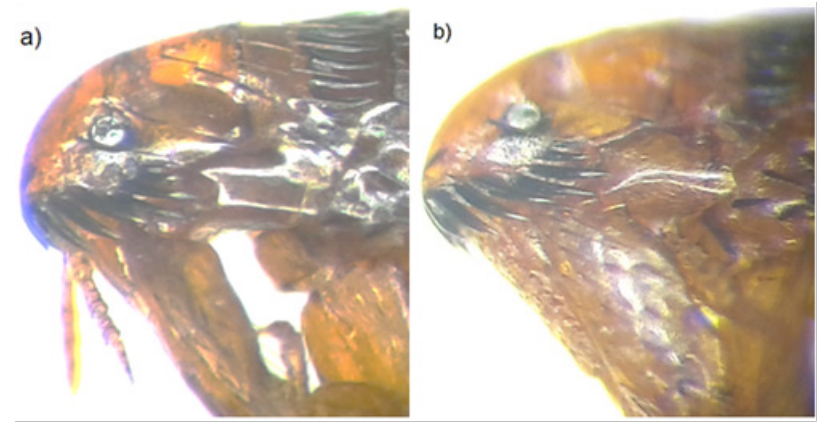

Figure 2 Differences between the two flea species.

(a) C. canis. Rounded head on its anterior portion, eyes present. The ctenidia has more than five spines; of which, the spnine I is distinctively shorter than the spine II.

(b) C. felis. Head larger and wide, eyes present. The ctenidia have six spines. The length of the first two spines is approximately similar.

\section{Conclusion}

The presence of $C$. felis and C. canis in domestic dogs should be considered by public health and veterinary authorities, due to the zoonotic risk of the pathogens present on these fleas. Further research is needed to determine the role of these ectoparasites in the dissemination of diseases in the study area.

\section{Acknowledgements}

Authors acknowledge the Mexican Council of Science and Technology (CONACYT) for the economic support. 


\section{Conflict of interest}

Authors declares there is no conflict of interest.

\section{References}

1. Bitam I, Dittmar K, Parola P, et al. Fleas and flea-borne diseases. Int $J$ Infect Dis. 2010;14(8):e667-e676.

2. McElroy KM, Blagburn BL, Breitschwerdt EB, et al. Flea associated zoonotic diseases of cats in the USA: bartonellosis, flea-borne rickettsioses, and plage. Trends Parasitol. 2010;26(4):197-204.

3. Acosta-Gutiérrez R. Biodiversidad de Siphonaptera en México. Rev Mex Biodivers. 2014;85:S345-352.

4. Beugnet F, Doyle V, Murray M, et al. Comparative efficacy on dogs of a single topical treatment with the pioneer fipronil/(S)-methoprene and an oral treatment with spinosad against Ctenocephalides felis. Parasite. 2011;18(4):325-331.

5. Azad AF, Radulovic S, Higgins JA, et al. Flea-borne ricketioses: ecologic considerations. Emerg Infect Dis. 1997;3(3):319-327.

6. Eisen RJ, Gage KL. Transmission of flea-borne zoonotic agents. Annu Rev Entomol. 2012;57:61-82.

7. Loftis AD, Reeves WK, Szumlas DE, et al. Surveillance of egyptian fleas for agents of public health significance: Anaplasma, Bartonella Coxiella, Ehrlichia, Rickettsia and Yersinia pestis. Am J Trop Med Hyg. 2006;75(1):41-48.

8. Assarasakorn S, Veir JK, Hawley JR, et al. Prevalence of Bartonella species, hemoplasmas, and Rickettsia felis DNA in blood and fleas of cats in Bangkok, Thailand. Res Vet Sci. 2012;93(3):1213-1216.

9. Torina A, Blanda V, Antoci F, et al. A molecular survey of Anaplasma spp., Rickettsia spp., Ehrlichia canis and Babesia microti in foxes and fleas from Sicily. Transbound Emerg Dis. 2013;60(2):125-130.

10. Cruz-Vázquez C, Castro-Gámez E, Parada-Fernández M, et al. Seasonal occurrence of Ctenocephalides felis felis and Ctenocephalides canis (Siphonaptera: Pulicidae) infesting dogs and cats in an urban area in Cuernavaca, Mexico. J Med Entomol. 2001;38(1):111-113.

11. Hernández-Valdivia E, Cruz-Vázquez C, Ortiz-Martínez R, et al. Presence of Ctenocephalides canis (Curtis) and Ctenocephalides felis (Bouché) infesting dogs in the city of Aguascalientes, Mexico. J Parasitol. 2011;97(6):1017-1019

12. Bolio-González ME, Rodríguez-Vivas RI, Sauri-Arceo $\mathrm{CH}$, et al Prevalencia y lesiones cutáneas de Ctenocephalides felis y Ctenocephalides canis en perros del estado de Yucatán, México. Bioagrociencias. 2012;5(1):15-19.

13. INEGI. Instituto Nacional de Estadística y Geografía. Prontuario de información geográfica municipal de los Estados Unidos Mexicanos. Gómez Palacio, Durango. 2010
14. NEGI. Instituto Nacional de Estadística y Geografía. Prontuario de información geográfica municipal de los Estados Unidos Mexicanos. Lerdo, Durango. 2010.

15. Rinaldi L, Spera G, Musella V, et al. A survey of fleas on dogs in southern Italy. Vet Parasitol. 2007;148(3-4):375-378.

16. CDC. Pictorial keys to arthropods, reptiles, birds and mammals of public health significance. Centers for Disease Control and Prevention: Atlanta, 2014. p. 167-174.

17. Orozco-Murillo JA, Sánchez-Pinzón MS, Jaramillo-Jaramillo M, et al. Frecuencia de Ctenocephalides canis y Ctenocephalides felis obtenidas de caninos infestados naturalmente en el Valle de Aburrá. CES Med Vet Zootec. 2008;3(2):73-77.

18. Nuchjangreed C, Somprasong W. Ectoparasite species found in domestic dogs from Pattaya District, Chon Buri Province, Thailand. Southeast Asian J Trop Med Public Health. 2011;38(1):203-207.

19. Jafari-Shoorijeh S, Rowshan-Ghasrodashti A, Tamadon A, et al. Seasonal frequency of ectoparasite infestation in dogs from Shiraz, Southern Iran. Turk J Vet Anim Sci. 2008;32(4):309-313.

20. Bahrami AM, Doosti A, Ahmady-Asbchin S. Cat and dogs ectoparasite infestations in Iran and Iraq boarder line area. World Appl Sci J. 2012;18(7):884-889.

21. Jamshidi S, Maazi N, Ranjbar-Bahadori S, et al. A survey of ectoparasite infestation in dogs in Tehran, Iran. Rev Bras Parasitol Vet.2012;21(3):326329.

22. Dobler G, Pfeffer M. Fleas as parasites of the family Canidae. Parasit Vectors, 2011;4:139.

23. Pfister K, Armstrong R. Systemically and cutaneously distributed ectoparasiticides: a review of the efficacy against ticks and fleas on dogs. Parasit Vectors. 2016;9(1):436.

24. Franc M, Bouhsira E. Evaluation of speed and duration of efficacy of spinosad tablets for treatment and control of Ctenocephalides canis (Siphonaptera: Pulicidae) infestations in dogs. Parasite. 2009;16:125128.

25. Bonneau S, Fourier JF, Rousseau C, et al. Comparative efficacy of two fipronil spot-on formulations against experimental flea infestations (Ctenocephalides felis) in dogs. Int J Appl Res Vet M. 2010;8(1):16-20.

26. Dumont P, Gale B, Chester TS, et al. Curative and preventive efficacy of orally administered afoxolaner against Ctenocephalides canis infestation in dogs. Vet Parasitol. 2014;201:212-215.

27. Ortega-Palomares JE, Nuñez-Palenius HG, Cruz-Avalos AM, et al. Ocurrence of entomopathogenic fungus from flea Ctenocephalides canis (Siphonaptera: Pulicidae). Open J Vet Med. 2014;4:281-285. 